\title{
PERANAN VISUM ET REPERTUM DALAM TINDAK PIDANA PENGANIAYAAN YANG MENGAKIBATKAN KEMATIAN
}

\author{
Manumpak Pane \\ Wakil Ketua Kejaksaan Tinggi Maluku \\ Korespondensi: manumpak.pane@yahoo.com
}

\begin{abstract}
Abstrak
Kejahatan korporasi merupakan salah satu tindak pidana yang timbul seiring dengan perkembangan perekonomian dan teknologi. Persoalan yang mengemuka yaitu bagaimana tanggung jawab perusahaan sebagai badan hukum, sementara dalam kaidah Hukum Pidana belum sepenuhnya menjangkau tindak pidana tersebut. Tulisan ini bermaksud menguraikan pertanggungjawaban pidana korporasi, utamanya pemegang saham dan direksi manakala ada tindak pidana yang dilakukan.
\end{abstract}

Kata-kata Kunci: Kejahatan, Korporasi, Direksi, Pemegang Saham.

\begin{abstract}
Corporate crime is a category of crimes that emerge along with the economic and technological development. The issue raised in this article is how is the criminal responsibility for the company as a legal entity. This is crucial since the rules of the Criminal Law has not fully reach the criminal act performed by corporations. This paper intends to outline the criminal liability of corporations, particularly their main shareholders and directors when there is a criminal offense committed.
\end{abstract}

Key Words: Crime; Corporation; Directors; Shareholders. 


\section{PENDAHULUAN}

Penggolongan berbagai tindak pidana dalam Kitab Undang-undang Hukum Pidana (KUHP) pada dasarnya merupakan upaya pembentuk undangundang untuk membedakan antara jenis tindak pidana yang satu dengan yang lain. Penggolongan berbagai tindak pidana dalam KUHP didasarkan pada kepentingan umum yang ingin dilindungi. Atas dasar kepentingan hukum yang ingin dilindungi tersebut dikenal berbagai penggolongan tindak pidana yaitu tindak pidana terhadap harta benda atau harta kekayaan, tindak pidana terhadap kehormatan dan tindak pidana terhadap badan/tubuh. Tindak pidana penganiayaan yang mengakibatkan kematian merupakan tindak pidana terhadap badan/tubuh.

Tulisan ini hendak membahas secara spesifik peranan Visum et Repertum dalam pembuktian tindak pidana penganiayaan yang mengakibatkan kematian. Dalam pengertian demikian maka tulisan ini berada di ranah hukum pidana formil, yaitu hukum acara pidana. Tujuan umum dari hukum acara pidana adalah untuk mencari dan menemukan, atau setidak-tidaknya mendekati, kebenaran materil yaitu kebenaran sejati (materiel warheid). Upaya mencari kebenaran materiil ini yang membedakan hukum acara pidana dengan hukum acara perdata. Pada hukum acara perdata kebenaran, yang ingin dicapai adalah kebenaran formal yaitu kebenaran yang didasarkan pada formalitas hukum.
Dalam hukum acara pidana ada beberapa pihak yang terlibat di dalamnya yaitu Polisi, Jaksa, dan Hakim. Ketiga pihak inilah yang nantinya diharapkan dapat mewujudkan tujuan dari hukum acara pidana itu sendiri dengan menerapkan secara jujur dan tepat ketentuan Kitab Undang-Undang Hukum Acara Pidana (KUHAP) dalam suatu perkara pidana sehingga siapa yang bersalah dapat dijatuhi hukuman dan sebaliknya yang tidak bersalah dibebaskan dari hukuman.

Melakukan penyidikan, penuntutan dan pemeriksaan di pengadilan, penyidik, penuntut umum dan hakim tidak terlepas dari ilmu pengetahuan lain dalam melaksanakan tugasnya sesuai bidangnya masing-masing. Salah satunya adalah ilmu kedokteran kehakiman atau kedokteran forensik. Ilmu kedokteran kehakiman adalah penggunaan ilmu kedokteran untuk kepentingan pengadilan yang mana ilmu kedokteran kehakiman itu sangat berperan dalam membantu pihak Kepolisian, Kejaksaan dan Kehakiman untuk menyelesaikan persoalan yang hanya dapat dipecahkan dengan ilmu pengetahuan ini.

Ilmu kedokteran kehakiman sangat berperan dalam membantu proses peradilan menyangkut peristiwa: terlukanya seseorang; terganggunya kesehatan seseorang; dan matinya seseorang. Dari akibat yang terjadi tersebut ada dugaan dari penyidik bahwa telah terjadi suatu tindak pidana. Untuk itu diperlukan bantuan dari 
seorang ahli untuk memecahkan persoalan tersebut. Permintaan bantuan ahli dinyatakan dalam Pasal 133 ayat (1) Undang-Undang Nomor 8 Tahun 1981 tentang Kitab Undang-undang Hukum Acara Pidana (KUHAP) yang menyatakan:

Hal penyidik untuk kepentingan peradilan menangani seorang korban baik luka, keracunan ataupun mati yang diduga karena peristiwa yang merupakan tindak pidana, ia berwenang mengajukan permintaan keterangan ahli kepada ahli kedokteran kehakiman atau dokter atau ahli lainnya.

Dari hasil pemeriksaan yang dilakukan oleh ahli kedokteran kehakiman atau dokter atau ahli lainnya atas korban atau barang bukti yang dikirim oleh penyidik, maka ahli tersebut akan membuat laporan dari hasil pemeriksaan yang telah dilakukannya dan kesimpulan dari ahli bersangkutan berdasarkan pengetahuan dan pengalaman yang dimilikinya. Laporan dari ahli ini disebut dengan istilah Visum et Repertum.

Dalam KUHAP tidak ditemukan istilah maupun pengertian spesifik Visum et Repertum, tetapi istilah keterangan ahli yang lebih umum yaitu apa yang seorang ahli nyatakan di persidangan baik tulisan dalam bentuk laporan maupun lisan yang disampaikan langsung di persidangan, di mana keterangan ahli yang diberikan dalam bentuk laporan ini telah tercakup di dalam Visum et Repertum.
Meskipun pengertian Visum et Repertum tidak tercantum secara tegas dalam KUHAP, namun sebagai pedoman dapat dijelaskan bahwa pengertian Visum et Repertum itu adalah: "Hasil dari pemeriksaan yang dibuat oleh dokter berdasarkan apa yang dilihatnya dan diketahuinya berdasarkan ilmu pengetahuan dan pengalaman yang dimilikinya guna kepentingan pengadilan."

Visum et Repertum sangat penting dalam suatu perkara pidana khususnya untuk peristiwa matinya seseorang yang diakibatkan oleh penganiayaan yang dilakukan dengan berbagai modus operandi karena umumnya barang bukti peristiwa tersebut tidak memungkinkan untuk dihadirkan dalam persidangan. Untuk itu penulis tertarik untuk membahas secara lebih mendalam peran dari ilmu kedokteran (kehakiman) dalam penegakan hukum, khususnya terhadap tindak pidana penganiayaan yang mengakibatkan kematian pada korban.

\section{PEMBAHASAN}

\section{Pengertian Visum et Repertum}

Istilah Visum et Repertum bukanlah istilah hukum melainkan istilah kedokteran. Oleh karena itu dapat dimaklumi bahwa masyarakat pada umumnya kurang memahami/ mengetahui pengertian dan sejauhmana peranan visum dalam proses hukum terhadap suatu tindak pidana, khususnya tindak pidana penganiayaan yang mengakibatkan kematian. 
Istilah Visum et Repertum berasal dari bahasa Latin yaitu 'Visum' (something seen, appearance atau sesuatu yang dilihat); 'et' (and atau dan); serta 'Repertum' (invention, find out atau ditemukan). Jadi pengertian Visum et Repertum adalah apa-apa yang dilihat dan ditemukan pada korban. Dalam pengertian bebas Visum et Repertum adalah keterangan tertulis dari seorang dokter atas sumpah jabatannya dengan permintaan tertulis dari pihak berwenang, mengenai apa yang dilihat dan/atau ditemukan pada barang bukti baik orang hidup atau mati untuk kepentingan peradilan (pro-justicia).

\section{Peranan Visum et Repertum dalam Tindak Pidana Penganiayaan Yang Mengakibatkan Kematian}

Visum et Repertum sebagai Alat Bukti

Pasal 183 KUHAP menentukan bahwa: "Hakim tidak boleh menjatuhkan pidana kepada seorang kecuali apabila dengan sekurangkurangnya dua alat bukti yang sah ia memperoleh keyakinan bahwa suatu tindakan pidana benar-benar terjadi dan bahwa terdakwa hanyalah yang bersalah melakukan." Alat bukti yang sah dalam proses pembuktian di pengadilan diatur dalam Pasal 184 ayat (1) KUHAP yaitu: keterangan saksi; keterangan ahli; surat; petunjuk; dan keterangan terdakwa.

Pembahasan selanjutnya akan difokuskan pada Visum et Repertum ini sebagai alat bukti surat, yaitu yang dibuat oleh dokter ahli kedokteran kehakiman. Menurut Andi Hamzah, surat adalah segala sesuatu yang mengandung tanda-tanda baca yang dapat dimengerti, dimaksud untuk mengeluarkan isi pikiran. ${ }^{1}$

Keterangan ahli bagi kelengkapan alat bukti dalam berkas perkara pro justicia dan pemeriksaan sidang pengadilan amat membantu dalam usaha untuk menambah keyakinan hakim dalam hal pengambilan putusan. Dalam pemeriksaan oleh hakim di persidangan, suatu berkas perkara pidana, apakah ada atau tidak ada Visum et Repertum, maka perkara yang bersangkutan tetap harus diperiksa dan diputus. Kelengkapan Visum et Repertum dalam berkas perkara terdakwa yang diperiksa oleh hakim, diserahkan kepada Penuntut Umum yang dimulai dengan diserahkannya berkas perkara pro justicia tersebut oleh Penyidik. Penuntut Umum harus berusaha untuk membuktikan dalam sidang agar Majelis Hakim yakin perihal terbuktinya tindak pidana tersebut.

Pada beberapa kasus yang diperiksa di pengadilan, Majelis Hakim sendiri tidak mutlak harus mendasarkan diri pada Visum et Repertum. Kekuatan pembuktian (bewijskracht) dari Visumet Repertum diserahkan pada penilaian hakim (Majelis Hakim). Oleh karena Penuntut Umum berusaha membuktikan kesalahan Terdakwa di persidangan, berarti beban pembuktian bagi perkara pidana ada pada Penuntut Umum, dalam usaha mencari kebenaran materiil, dan hakim tetap dibatasi pada 
alat-alat bukti yang diajukan olehnya sesuai KUHAP. Jika Penuntut Umum tidak bersedia menambah alat bukti yang hanya minimum, maka hakim tidak dapat mencari sendiri alat bukti tambahan.

Pada prinsipnya Terdakwa tidak dibebani kewajiban pembuktian. Hal tersebut sesuai dengan asas praduga tidak bersalah (presumption of innocence) sebagai asas dalam hukum acara pidana. Asas ini memiliki pengertian bahwa seorang terdakwa harus dianggap tidak bersalah, sebelum kesalahan tersebut dinyatakan terbukti oleh suatu putusan hakim serta telah mempunyai kekuatan hukum yang tetap. Oleh karena itu, atas dasar asas tersebut, Pasal 66 KUHAP menentukan bahwa Tersangka atau Terdakwa tidak dibebani kewajiban pembuktian.

Pasal 183 KUHAP menentukan bahwa yang diperlukan oleh hakim dalam menjatuhkan pidana kepada seseorang adalah: adanya dua alat bukti yang sah (sekurang-kurangnya); keyakinan; bahwa tindak pidana itu benar terjadi; dan bahwa terdakwalah yang bersalah berbuat.

Pengaturan Visum et Repertum dalam Perundang-Undangan Indonesia

KUHAP secara implisit mengatur tentang Visum Et Repertum dalam beberapa pasal. Pertama, Pasal 133 ayat (1) KUHAP yang berbunyi: "Dalam hal penyelidikan untuk kepentingan peradilan mengenai seorang korban, baik luka, keracunan maupun mati yang diduga karena peristiwa yang merupakan tindak pidana, berwenang mengajukan permintaan keterangan ahli kedokteran kehakiman atau dokter dan/ atau ahli lainnya." Pasal 133 ayat (2) KUHAP menentukan: "Permintaan keterangan ahli sebagaimana yang dimaksud dalam ayat (1) dilakukan secara tertulis, yang dalam surat itu disebutkan dengan tegas untuk pemeriksaan luka atau pemeriksaan mayat dan/atau pemeriksaan bedah mayat."

Selanjutnya pada Pasal 134 ayat (1) KUHAP ditentukan: "Hal sangat diperlukan dimana untuk keperluan pembuktian bedah mayat tidak mungkin lagi dihindari, penyidik wajib memberitahukan terlebih dahulu kepada keluarga korban." Terkait dengan implementasi ketentuan tersebut maka Pasal 134 ayat (2) KUHAP mengatur: "Hal keluarga keberatan, penyidik wajib menerangkan dengan sejelas-jelasnya tentang maksud dan tujuan perlu dilakukannya pembedahan tersebut." Terakhir Pasal 135 KUHAP yang berbunyi: "Hal penyidik untuk kepentingan peradilan perlu melakukan penggalian mayat, dilakukan menurut ketentuan sebagaimana dimaksud dalam Pasal 133 ayat (2) dan Pasal 134 ayat (1) undang-undang ini."

Selain dalam KUHAP, dalam KUHP juga terdapat pengaturan Visum et Repertum secara implisit, yakni Pasal 222 KUHP yang berbunyi: "Barang siapa dengan sengaja menghalang-halangi, merintangi atau menggagalkan pemeriksaan mayat untuk pengadilan, 
dihukum penjara selama-lamanya sembilan bulan atau setinggi-tingginya Rp. 4.500." Kemudian Pasal 216 (1) KUHP yang berbunyi: "Barang siapa dengan sengaja tidak menurut perintah atau tuntutan, yang dilakukan menurut peraturan undang-undang, oleh pegawai negeri yang diwajibkan mengawas-awasi pegawai negeri yang diwajibkan atau yang dikuasakan untuk menyelidiki atau memeriksa perbuatan yang dapat dihukum, demikian juga barang siapa dengan sengaja mencegah, merintangi atau menggagalkan sesuatu perbuatan yang dilakukan oleh salah seorang pegawai negeri itu, dalam menjalankan sesuatu peraturan undang-undang, dihukum penjara selama-lamanyan empat bulan dua minggu atau denda setinggi-tingginya Rp 9.000.” Sedangkan pada Ayat (2)-nya ditemukan ketentuan: "Yang disamakan dengan pegawai negeri yang dimaksud dalam bahagian pertama dari ayat di atas ini, ialah segala orang yang menurut peraturan undangundang selalu atau sementara diwjibkan menjalankan sesuatu pekerjaan umum."

\section{Nilai Pembuktian Visum et Repertum}

Pasal 133 ayat (1) KUHAP menyebutkan bahwa: "Dalam hal penyelidikan untuk kepentingan peradilan mengenai seorang korban, baik luka, keracunan maupun mati yang diduga karena peristiwa yang merupakan tindak pidana, berwenang mengajukan permintaan keterangan ahli kedokteran kehakiman atau dokter dan atau ahlinya." Ayat (2)-nya berbunyi: "Permintaan keterangan ahli sebagaimana yang dimaksud dalam ayat
(1) dilakukan secara tertulis, yang dalam surat itu disebutkan dengan tegas untuk pemeriksaan luka atau pemeriksaan mayat dan/atau pemeriksaan bedah mayat." Sementara itu Penjelasan Pasal 133 ayat (2) KUHAP menyebutkan bahwa keterangan yang diberikan ahli kedokteran kehakiman tersebut disebut keterangan.

Barang-barang yang diperiksa oleh dokter, baik itu orang hidup, jenazah, organ tubuh, atau benda yang didapat dari dalam tubuh adalah merupakan barang bukti. Kedudukannya tidak berbeda seperti benda bukti lainnya yang didapat dari tempat kejadian atau tempat lain yang disita oleh penyidik. Hal ini sesuai dengan ketentuan Pasal 39 KUHAP yang berbunyi: "Yang dapat dikenakan penyitaan adalah:

a. Benda atau tagihan tersangka atau terdakwa yang seluruh atau sebagai hasil dari tindak pidana;

b. Benda yang telah telah dipergunakan secara langsung untuk melakukan tindakan pidana atau untuk mempersiapkannya;

c. Benda yang dipergunakan untuk menghalang-halangi penyidikan tindakan pidana;

d. Benda yang khusus dibuat atau diperuntukkan melakukan tindakan pidana;

e. Benda lain yang mempunyai hubungan langsung dengan tindakan pidana yang dilakukan.

Di sini orang yang menderita luka, organ tubuh, atau benda lain yang didapat dari tubuh merupakan barang 
atau benda yang mempunyai hubungan langsung dengan tindak pidana. Sedangkan maksud penyitaan adalah untuk keperluan penyidikan, penuntutan dan pemeriksaan di dalam sidang pengadilan nanti.

Selanjutnya, untuk menjaga serta mencegah adanya kekeliruan dengan benda lain yang tidak ada hubungan dengan perkara yang bersangkutan, benda sitaan itu harus disegel seperti yang disyaratkan oleh Pasal 130 KUHAP yang berbunyi:

1. Benda sitaan sebelum dibungkus, dicatat berat dan atau jumlah menurut jenis masing-masing. Ciri maupun sifat khas, tempat, hari, dan tanggal penyitaan, identitas orang dari mana benda itu disita dan lain-lainnya yang kemudian diberi lak dan cap jabatan dan ditanda tangani penyidik.

2. Benda sitaan tidak mungkin dibungkus, penyidik memberikan catatan sebagaimana dalam ayat (1), yang ditulis di atas label yang ditempelkan atau dikaitkan pada benda tersebut.

Pada sidang nanti, benda-benda tersebut oleh hakim ditunjukkan, bila perlu, kepada saksi-saksi seperti disebut dalam Pasal 181 KUHAP yang berbunyi:

1. Hakim Ketua memperlihatkan terdakwa segala segala barang bukti dan menanyakan kepadanya apakah ia mengenal barang tersebut dengan memperlihatkan ketentuan sebagaimana dimaksud dalam Pasal 45 undang-undang ini.
2. Bila perlu benda itu diperlihatkan juga oleh hakim ketua sidang kepada saksi.

3. Apabila dianggap perlu untuk pembuktian, hakim ketua sidang membacakan atau memperlihatkan surat atau berita acara kepada terdakwa atau saksi dan selanjutnya minta keterangan tentang hal itu.

Fungsi barang-barang bukti tersebut adalah dapat menambah keyakinan hakim tentang tindak pidana yang didakwakan kepada terdakwa. Masalahnya sekarang, apakah mungkin menyita atau menyegel orang yang luka atau jenazah? Karena seorang yang luka-luka apabila tidak terdapat pengobatan, keadaannya akan memburuk, atau si penderita luka meninggal dunia. Sedangkan atas jenazah tidak mungkin menunggu sampai perkaranya disidangkan.

Kemudian hasil pemeriksaan pendahuluan yang telah dituangkan ke dalam berkas penyidikan dilimpahkan oleh Penyidik kepada Jaksa Penuntut Umum untuk penyusunan surat dakwaan. Antara Penyidik dan Jaksa Penuntut Umum mempunyai hubungan timbal balik sebelum jaksa melimpahkan berkas perkara, termasuk Visum et Repertum, ke pengadilan.

Setelah di persidangan Visum et Repertum masuk ke dalam Pasal 187 KUHAP, sedangkan apabila hakim memanggil langsung pembuat Visum et Repertum itu ke depan persidangan maka keterangan yang diberikan oleh dokter menjadi keterangan asli. Setelah 
melalui beberapa tahap atau proses, sebagai akhir dari proses/tahapan itu adalah pembuatan putusan oleh hakim. Putusan yang dibuat oleh hakim sebagai kesimpulan dari seluruh proses pemeriksaan terhadap alat-alat bukti harus didasarkan pada keyakinannya.

Sutomo Tjokronegoro menguraikan bahwa sesuai dengan arti yang terkandung di dalamnya yakni, apa yang dilihat dan ditemukan, maka maksud Visum et Repertum adalah memberi rencana yang sesungguhnya dan seobjektif-objektifnya tentang apa yang dilihat dan didapatinya pada waktu ia melakukan pemeriksaan rencana itu, yang mana hal tersebut bertujuan untuk:

a. Memberi kenyataan-kenyataan (feiten) kepada hakim yang memimpin persidangan agar berdasarkan kenyataan-kenyataan yang diperoleh dengan jalan lain, serta berdasarkan hubungan sebab akibat (leer der causaliteit) dapat diambil keputusan yang tepat;

b. Memungkinkan ahli kedokteran lain yang dipanggil hakim untuk mempertimbangkan kesimpulan ahli kedokteran yang membuat Visum et Repertum itu. Hal ini dapat terjadi bila hakim tidak setuju dengan kesimpulan pembuat Visum et Repertum itu tetapi tidak dapat hadir, sedangkan masih diperlukan keterangan lebih lanjut. ${ }^{2}$
Berdasarkan penjelasan di atas dapat dikatakan bahwa Visum et Repertum itu harus dapat mengganti sepenuhnya benda yang diperiksa dan yang menjadi tanda bukti dalam tindakan pidana. Hal ini harus diinsafi benar-benar. Pada tindakan pidana pencurian atau pemalsuan maka barang yang dicuri atau dipalsukan itu dapat diajukan sebagai bukti di depan persidangan. Tetapi di dalam tubuh, terdapat bukti-bukti di tubuh manusia itu sudah berubah atau lebih buruk dari semula, atau dengan kata lain tanda bukti yang demikian itu tidak dapat diajukan ke depan persidangan.

Hal yang sering dijumpai dalam Visum et Repertum yang dapat berpengaruh terhadap kelancaran pemeriksaan perkara pada umumnya dan memungkinkan hakim memanggil kembali pembuat Visum et Repertum adalah:

a. Terdapat istilah-istilah kedokteran, atau istilah-istilah asing di dalam Visum et Repertum yang pada umumnya kurang dipahami oleh hakim, oleh karena itu diperlukan penjelasan lebih lanjut sehingga dapat dimengerti dan dipahami oleh hakim sebagai tenaga non-medik.

b. Terdapatnya kolom-kolom yang sering dibiarkan tidak diisi atau dicoret sesuai hasil pemeriksaan dokter atas korban terutama pada bagian kesimpulan dari Visum et Repertum sehingga tidak jelas apakah ada hubungan perbuatan pidana dengan akibat yang timbul.

2 Sutarno Tjokronegoro, Beberapa Hal Tentang Ilmu Kodekteran Kehakiman (Pustaka Rakyat N.V. 1952) 26. 
Menurut M. Yahya Harahap, dari sudut materiil, alat bukti surat bersifat bebas. Artinya, hakim bebas untuk menilai kekuatan pembuktiannya.

\section{Hubungan Kausalitas Penganiayaan dengan Kematian Korban}

Dalam beberapa pasal KUHP ditentukan tindakan yang dilarang atau diharuskan yang merupakan penyebab (causal) dari suatu akibat tertentu. Perumusan penyebab tersebut antara lain ialah: penganiayaan (Pasal 351 ayat (3) KUHP). Kelakuan/tindakan tersebut adalah merupakan sebab (causal, oorzaak) dari kematian seseorang. Untuk pemenuhan unsur-unsur dari delik-delik tersebut, tidak disyaratkan lagi mencari sebab dari kelakuan/ tindakan tersebut lebih jauh ke depan. Dan pula tidak diperlukan untuk mencari atau mengungkapkan akibat lebih jauh ke belakang dari yang telah ditentukan.

Visum et Repertum sangat berperan dalam menentukan hubungan kausalitas antara penganiayaan dengan kematian korban, yaitu dengan mengadakan pemeriksaan terhadap korban yang dilakukan oleh pembuat Visum et Repertum. Dari Visum et Repertum akan dilihat apa yang menjadi penyebab dari kematian korban. Pembuat visum akan memeriksa apakah ada hal-hal lain (misalnya penyakit), yang diderita oleh si korban yang merupakan penyebab dari kematian. Di dalam Visum et Repertum akan diuraikan apa yang menjadi sebab-sebab kematian korban.

\section{Menentukan Apakah Tindak Pidana yang Terjadi Penganiayaan yang Mengakibatkan Kematian atau Pembunuhan}

Visum et Repertum memiliki peran strategis dalam menentukan tindak pidana yang terjadi, apakah merupakan tindak pidana penganiayaan yang mengakibatkan kematian atau pembunuhan. Hal ini dapat dilihat dari jangka waktu kematian korban dengan waktu tindak pidana terjadi. Apabila korban mati seketika tindakan pidana terjadi maka tindakan pidana yang terjadi adalah tindakan pidana pembunuhan, sedang apabila korban tidak mati seketika tindak pidana terjadi, tetapi masih mempunyai jangka waktu (misalnya masih sempat dibawa kerumah sakit dan dokter masih sempat memberi pertolongan) maka tindakan pidana yang terjadi adalah tindakan pidana penganiayaan yang mengakibatkan kematian. Untuk melihan jangka waktu kematian ini dapat dilihat dari Visum et Repertum.

Selain dengan Visum et Repertum hakim juga dapat membuktikan tindakan pidana yang terjadi, yaitu dengan melihat niat dan tujuan yang ingin dituju oleh pelaku. Tindakan pidana pembunuhan, akibat kematian adalah tujuan pelaku. Sedangkan dalam tindakan pidana penganiayaan yang mengakibatkan kematian korban bukan merupakan tujuan dari pelaku. Pelaku hanya menginginkan rasa sakit atau luka tubuh pada korban. 


\section{PENUTUP}

Berdasarkan uraian di atas penulis menarik kesimpulan yaitu sebagai berikut. Tindak pidana penganiayaan yang mengakibatkan kematian harus dapat dibuktikan hubungan kausalitas antara perbuatan penganiayaan dengan kematian korban. Pembuktian tersebut, apabila tidak ada hubungan kausalitas antara penganiayaan dengan kematian korban, maka pelaku hanya didakwakan melakukan delik penganiayaan (Pasal 351 ayat (1) KUHP). Dalam pembuktian, apabila aparat penegak hukum mengalami kesulitan, maka aparat hukum tersebut dapat meminta bantuan seorang dokter kehakiman. Laporan yang dibuat oleh dokter kehakiman dibuat dalam bentuk surat yang lazim disebut dengan istilah Visum et Repertum.

Peranan Visum et Repertum adalah sebagai alat bukti tertulis bagi hakim di dalam pemeriksaan perkara penganiayaan atau alat bukti bagi tindak pidana pembunuhan. Dari Visum et Repertum akan dapat dilihat apa yang menjadi penyebab dari kematian korban. Pembuat visum akan memeriksa apakah ada hal-hal lain (misalnya penyakit), yang diderita oleh si korban, yang merupakan penyebab dari kematian.
DAFTAR BACAAN

Hamzah, Andi, Hukum Acara Pidana Indonesia (Sinar Grafika 2005).

Tjokronegoro, Sutarno, Beberapa Hal Tentang Ilmu Kodekteran Kehakiman (Pustaka Rakyat N.V. 1952). 